\title{
MODEL OF TECHNOLOGICAL LINE FOR BOTTLING OF FRUIT JUICES
}

\author{
Slawomir Francik, Boguslawa Lapczynska-Kordon, Karolina Slomka-Polonis, Adrian Knapczyk \\ University of Agriculture in Krakow, Poland \\ slawomir.francik@urk.edu.pl,boguslawa.lapczynska-kordon@urk.edu.pl, karolina.slomka- \\ polonis@urk.edu.pl, adrian.knapczyk91@gmail.com
}

\begin{abstract}
The paper presents a relational model of a technological line used for bottling fruit juices, which constitutes a stage of works aimed at building mathematical and simulation models. The model has been developed using the system analysis method. A relational model is defined as a pair of relations between a set of model elements and a relational structure. Creation of this model is a work stage approaching the construction of mathematical and simulation models. Relation model was developed with the system analysis method developed by Jaros and Pabis. The creation of the empirical system model is carried out in several stages: analysis of the system and its structure, mapping selected system objects into model elements, creating a relational model, analysis of states that are important for the purpose of modelling for each object in the system, formulation of mathematical models, assessing the compliance of the block diagram of the model operation with the model's relational structure, development of an operational model, programming the operating model. In this publication, we present the first three stages of model creation. The analysis of the complex empirical system of the modelled fruit juice bottling line made it possible to create a system diagram and isolate 24 objects of the actual system. The representation of a set of system objects as a set of model elements made it possible to obtain a relational model consisting of 6 elements and a set of 16 relations, which form the structure of the model. The elements of the relational model include a blower, monobloc, packaging unit, labelling device, transport equipment, check and repair service. In addition, the model includes forklift trucks as an element of the environment. The formulated relational model provides the basis for the development of an operational model and its logical acceptance.
\end{abstract}

Keywords: relational model, complex system, technological line, fruit juice.

\section{Introduction}

One of the most difficult tasks of the managerial staff working in industrial plants is to ensure the continuity of production and obtain an assumed high-quality product. In order to meet these challenges, it is necessary to make the right (optimal) decisions. This is not an easy task as - apart from routine decisions - it is often necessary to make decisions in response to unexpected situations that occur for the first time. Not only is it important to make the right decision, but it is also vital to make it at the right time, especially when indecisiveness involves downtime. Therefore, various tools are used to support the decision-making process in order to optimize and accelerate it [1-4]. One possibility is to create a model of a given production process and then use it for computer simulation [5-9]. An example of the use of simulation models to support decisions on agricultural engineering issues is the conceptual decision-making model for the management of a crop irrigation system in France [10], modelling of evaporators (conventional and with mechanical vapour recompression) for predicting a milk powder process trends and to compare energy consumption [11] and the use of generalised models of various machine use systems in agricultural holdings to assess the costs of individual operations and select the optimum solutions [12] . Computer simulation enables, among other things, the analysis of the operation of a technological line with different control parameter values or changing environmental conditions.

The system-based approach was used, among others, to describe cereal harvesting and transport systems by means of relational models [13], develop relational and mathematical models for the production and use of renewable energy sources [14], mathematically describe the system for the maintenance of selected machines in agro-food industry [15], an integrated energy system in a residential building [16], model databases [17] and create a relational model describing the process of harvesting and transporting apples in a fruit-growing holding [18].

One of the possibilities of developing an empirical system model is to use the methodology developed by Jaros and Pabis [19]. A model is created in several steps:

- analysis of the system and its structure;

- representation of selected system objects as model elements;

- creation of a relational model; 
- analysis of states that are important for the purpose of modelling for each object in the system;

- formulation of mathematical models;

- assessing the compliance of the block diagram of the model operation with the model's relational structure;

- development of an operational model;

- programming the operating model.

Not only relational models are used in design processes of the food branch. The production planning and scheduling problem in brewery facilities and in soft drink plants can be modeled by Mixed Integer Programming [20; 21]. Wang [22] used CAD tools in order to build virtual simulation model of beer-packaging production line (kinematical model for main machines). Models for automatic fault diagnosis in bottling plants have been developed [23; 24] - numerical simulation models were implemented in MATLAB/SIMULINK software. Various specialized computer programs were appropriate for modeling processes and technology assessment in brewing. Software tools, such as BATCHES, have been applied for modelling and optimisation of brewhouses and a "Brewery Model" (developed on Engineering Equation Solver) allows to generate energy balance of a brewing facility [25].

\section{The aim and scope of the work}

The aim of the paper is to create a relational model, which will serve as a starting point for building a mathematical model and a simulator of the operation of a technological line designed for bottling fruit juices.

Technological lines of this type are complex empirical systems with a high degree of complication and therefore it is necessary to apply an appropriate methodology to carry out the modelling process. The juice bottling line is a complex system because it consists of a large number of objects linked together by various relations that can be described by multiple characteristics. The first three stages of the creation of the empirical system model were completed according to the methodology developed by Jaros and Pabis [19]:

- analysis of the system and its structure;

- representation of selected system objects as model elements;

- creation of a relational model.

\section{Analysis of the system and its structure}

The technological line being modelled is composed of machines and devices of the highest technical level, which ensure the sterility of the process (the line is equipped with sterilization and washing devices). The complete cycle of the juice bottling line includes 120 hours of production, followed by an 8 -hour break for cleaning and sterilising the line. The analysis of the complex empirical system of the modelled fruit juice bottling line made it possible to create a diagram of the system (Fig. 1) and isolate the objects of the actual system:

$$
\sigma_{o}=\left\{R b, S b, P b, R n, Z a, C h, E t, D r, P k, O w, S z, S p, U n, U w, U p, U c, P_{i}, Z_{i}, T_{i}, N_{i}, B_{i}, C z, S w\right\},
$$

where $R b$-bottle preform blower;

$S b$ - sterilizer (a device for bottle sterilization);

$\mathrm{Pb}$ - washer (a bottle washing device);

$R n$ - bottler (a device for filling bottles with juice);

$\mathrm{Za}$ - bottle capper

Ch-CHECK (a device for checking the filling level and correctness of bottle capping);

$E t$ - labeller;

$\mathrm{Dr}$ - printer;

$P k$ - packaging machine (a machine for wrapping unit packagings in shrink film);

$P a$ - palletiser (a device for assembling case packs);

$O w$ - shrink-wrapper to wrap case packs on pallets;

$S z$ - bottle cap sterilizer;

$S p$ - sterile air system; 
$U n$ - disinfectant preparation device (UNIDOX);

$U w$ - water sterilization device (UNITHERM H);

$U p$ - washer foam preparation device (UNIFOAM);

$U c-$ lye and acid preparation device for the bottler and the bottle capper (UNICLEAN);

$P_{i}=\left\{P_{1}, \ldots, P_{12}\right\}-$ collection of pallets needed on the production line and pallets with the final product which are ready for storage;

$Z_{i}=\left\{Z_{1}, Z_{2}\right\}-$ collection of dispensers that provide the equipment with the means of production;

$T_{i}=\left\{\mathrm{T}_{1}, \ldots, \mathrm{T}_{6}\right\}-$ collection of means of transport (conveyors and pipelines);

$N_{i}=\left\{N_{1}, \ldots, N_{d}\right\}$ - set of additional means needed for production ("necessary items"

such as caps, preforms, foam, labels and shrink-wrap);

$B_{i}=\left\{B_{1}, \ldots, B_{k}\right\}-$ bottle (bottle condition: after blowing, after sterilization, after

capping, after printing);

$C z$-employees operating various machines and equipment ("man”);

$S w$ - repair service.

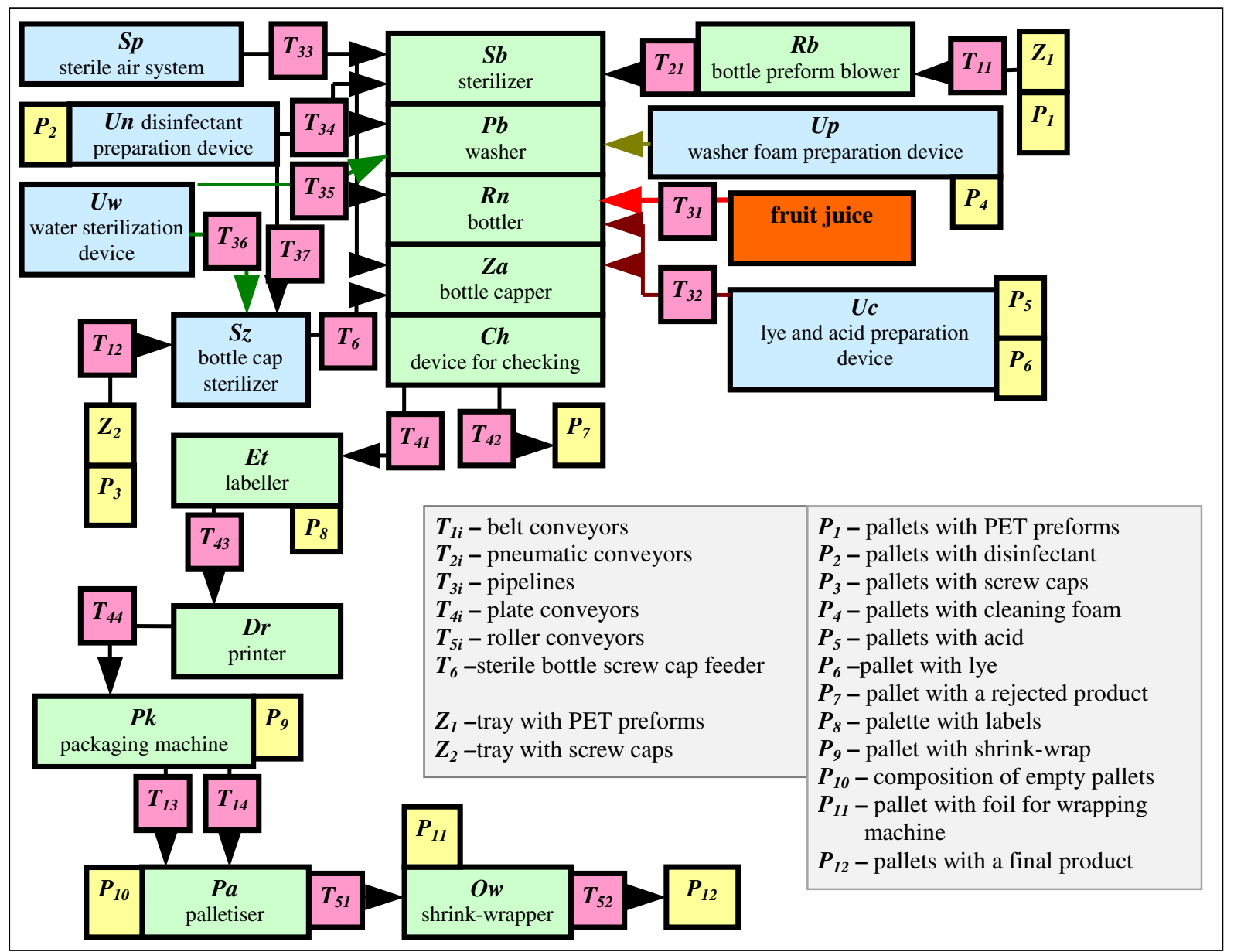

Fig. 1. Diagram of modelled juice bottling line

\section{Representation of selected system objects as model elements}

The next stage of modelling the system is the analysis of the possibility of aggregating a set of system objects, i.e. simplifying its functional structure. The stage involves making assumptions to simplify the structure of the system and selecting the relevant main objects that are necessary for the system to function properly. For the purposes of this paper, it has been assumed that employees can be assigned to the equipment they operate, as only the human-machine object can conduct the technological process.

The complex system has been simplified by combining those of its objects that make up functional units (using a homomorphic mapping). The aggregation method is presented in Fig. 2. 
After extracting the system's main objects, the isomorphic mapping of the main objects into the elements of the model was applied and the attributes (features) important for the purpose of modeling were assigned to them:

- $S R \rightarrow r$ \{selected features: bottle preform blower performance, a number of employees, a number of preforms on the pallet, frequency of failures, time of failure removal $\}$;

- $S M \rightarrow m$ \{selected features: monobloc performance, a number of employees, a number of screw caps on the pallet, frequency of failures, time of failure removal $\}$;

- $S C \rightarrow c$ \{ selected features: device for checking performance, a number of defective bottles in one hour, a number of rejected bottles on the pallet, frequency of failures, time of failure removal\};

- $S E \rightarrow e$ \{selected features: labeller performance/ labeling efficiency, a number of employees, a number of labels on a pallet, frequency of failures, time of failure removal $\}$;

- $S P \rightarrow p$ \{selected features: packing efficiency, a number of employees, the amount of a shrink-wrap foil on the pallet, hourly consumption of a shrink-wrap foil, a number of empty pallets stored at the production line, the amount of foil for wrapping on a pallet, a number of pallets with a final product that can be stored at the production line, frequency of failures, time of failure removal\};

- $S N \rightarrow n$ \{selected features: a number of employees, frequency of failures, types of failure, failure diagnosis time, time of failure removal $\}$.


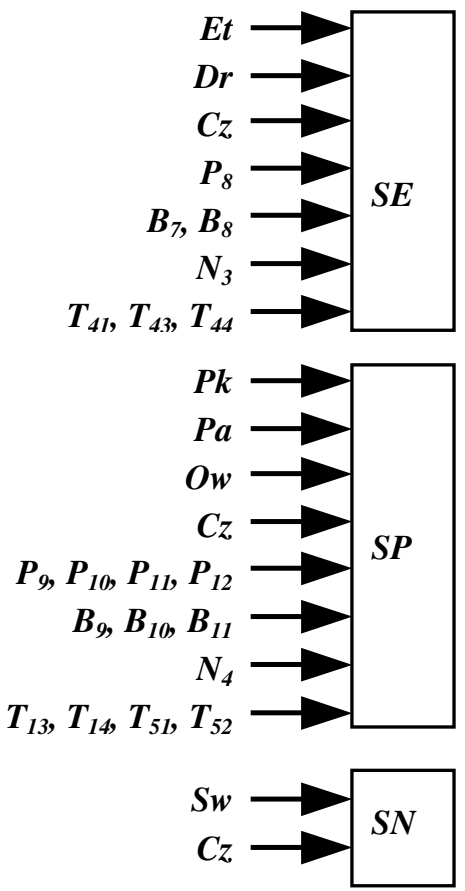

Fig. 2. Aggregation of system objects into main objects of modeled juice bottling line: SR - stand for blowing preforms, SM - stand for filling and screwing bottles (monobloc), SC - stand for checking, SE - labeling stand, SP - stand for packing, SN - repair service

The collection of twenty-four objects of the empirical system was represented as a collection of six model elements:

$$
\sigma_{e}=\{r, m, c, e, p, n\},
$$

where $r$-blower;

$m$ - monobloc;

$c$ - check;

$e$ - labeller;

$p$ - packaging machine; 


$$
\begin{aligned}
& m-\text { monobloc; } \\
& n-\text { repair service. }
\end{aligned}
$$

In the model an entourage element was taken into consideration: o1 - forklift trucks (transport of the final product and means necessary for production).

In the case of an isomorphic representation, each object is assigned a corresponding element in the model. In the case of a homomorphic representation, the power of a set of objects is greater than the power of a set of elements - a set of objects is aggregated in a set of model elements. Thus, it is possible to assign several objects to one element.

\section{Creation of a relational model}

The relational model is defined as a pair of relations of a model element set and a relational structure [19] :

$$
M^{R}=\left\langle E, S^{R}\right\rangle,
$$

set $E$ consists of the following elements:

$$
E=\{m, r, c, e, p, n, o 1\},
$$

The structure of the relational model with the elements from set $E$ is a subset of the Cartesian square $E^{2}$ :

$$
S^{R} \subseteq E \times E,
$$

Out of all possible relation pairs, a subset of 16 relevant relations was selected using the expert knowledge about the analysed system, thus forming the $S^{R}$ model structure:

$$
\begin{array}{r}
S^{R}=\{\langle m, c\rangle,\langle m, n\rangle,\langle r, n\rangle,\langle c, m\rangle,\langle c, n\rangle,\langle e, p\rangle,\langle e, n\rangle,\langle p, n\rangle,\langle p, o 1\rangle, \\
\langle n, m\rangle,\langle n, r\rangle,\langle n, c\rangle,\langle n, e\rangle,\langle n, p\rangle,\langle n, o 1\rangle,\langle o 1, n\rangle\},
\end{array}
$$

The model's relational structure $\left(S^{R}\right)$ is presented as a matrix in Table 1. An existing relation is marked as " 1 " and the lack of a relation is marked as " 0 ".

\section{The matrix of relations between the model elements}

Table 1

\begin{tabular}{|c|c|c|c|c|c|c|c|}
\hline $\boldsymbol{x}$ & $\mathbf{r}$ & $\boldsymbol{m}$ & $\boldsymbol{c}$ & $\boldsymbol{e}$ & $\boldsymbol{p}$ & $\boldsymbol{n}$ & $\boldsymbol{o} 1$ \\
\hline $\boldsymbol{r}$ & 1 & 0 & 0 & 0 & 0 & 1 & 0 \\
\hline $\boldsymbol{m}$ & 0 & 1 & 1 & 0 & 0 & 1 & 0 \\
\hline $\boldsymbol{c}$ & 0 & 1 & 1 & 0 & 0 & 1 & 0 \\
\hline $\boldsymbol{e}$ & 0 & 0 & 0 & 1 & 1 & 1 & 0 \\
\hline $\boldsymbol{p}$ & 0 & 0 & 0 & 0 & 1 & 1 & 1 \\
\hline $\boldsymbol{n}$ & 1 & 1 & 1 & 1 & 1 & 1 & 1 \\
\hline $\boldsymbol{o} 1$ & 0 & 0 & 0 & 0 & 0 & 1 & 1 \\
\hline
\end{tabular}

The model's relational structure is also presented in the form of a relational graph (Figure 3).

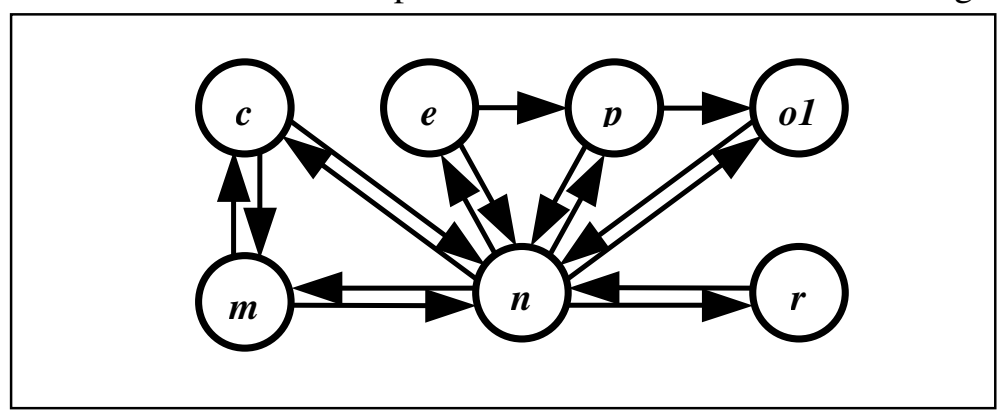

Fig. 3. Graph of relational model structure

The relations selected for the modelling purpose and forming the structure of the model can be justified as follows: 
- relation $\langle m, c\rangle$ - determines the relation between the monobloc and the device controlling the filling level and the correctness of the bottle capping (CHECK); the correctness of the work performed by the monobloc ends in the acceptance or rejection of the product;

- relation $\langle m, n\rangle$ - shows the relation between the monobloc and repairs; the intensity of damage and the type of damage to the monobloc affect the repair time;

- relation $\langle r, n\rangle$ - means the relation between the blower and repairs; the intensity of damage and the type of damage to the blower affect the repair time;

- relation $\langle c, m\rangle$ - determines the relation between the CHECK control device and the monobloc; in case the bottle sterilizer performs its task incorrectly, the CHECK issues an instruction to the bottler to fill the bottle only halfway; when the bottle reaches the CHECK device after it has been capped, it will be rejected;

- relation $\langle c, n\rangle$ - shows the impact of the control device on repairs; the intensity of damage and the type of damage to the CHECK device affect the repair time;

- relation $\langle e, p\rangle$ - shows the relation between the label object and the packaging of the finished bottles; an incorrectly labelled bottle will not be sealed in a multi-pack;

- relation $\langle e, n\rangle$ - means the impact of the label object on repairs; the intensity of damage and the type of damage (labeller and printer) affect the repair time,

- relation $\langle p, n\rangle$ - shows the relation between packaging and repairs; the intensity and type of damage to the packaging machine, palletiser or shrink-wrapper affect the time of their repair;

- relation $\langle p, o 1\rangle$ - determines the impact of packaging on forklift trucks; an incorrectly packed pallet may hinder or prevent transportation by a forklift truck;

- relation $\langle n, m\rangle$ - means the relation between repairs and the monobloc; the time of the repair of individual devices within the monobloc reduces the time of the effective operation of the entire monobloc;

- relation $\langle n, r\rangle$ - shows the relation between the repairs and the blower; the time of the repair of the blower reduces the time of the effective operation of the entire technological line;

- relation $\langle n, c\rangle$ - means the impact of repairs on the CHECK control device; the time of the repair of the device reduces the time of the effective operation of the entire line;

- relation $\langle n, e\rangle$ - determines the relation between repairs and the label object; the time of the repair of the labeller and the printer reduces the time of the effective operation of the technological line;

- relation $\langle n, p\rangle$ - shows the relation between repairs and packaging; the time of the repair of the packaging machine, palletiser or shrink-wrapper reduces the time of the effective operation of the entire bottling line;

- relation $\langle n, o 1\rangle$ - indicates the impact of repairs on the forklift trucks; the repair time reduces the time of the effective operation of the forklift truck;

- relation $\langle o 1, n\rangle$ - shows the relation between the forklift trucks and repairs; the intensity of damage and the type of damage to the trucks affect the repair time.

\section{Conclusions}

1. In the paper, a relational model of a physical system, i.e. a technological line for bottling food liquids, was built using a system-based approach.

2. An analysis of the complex empirical system was used to distinguish the main objects of the system. These objects were assigned characteristics that were relevant for the purpose of the modelling.

3. As a result of the representation of the objects, a set of model elements was created, which included: a blower, monobloc, packaging unit, labelling device, transport equipment, check and repair service. These elements were combined in relations that formed the structure of the relational model, which reflects the process of bottling and packaging fruit juice. This structure consists of an 18-element set of relations. The produced relational model serves as a starting point for building mathematical and simulation models.

4. The aim of the paper was to create a relational model (the first three stages of the empirical system modeling process). Our next task will be the accomplishment of subsequent stages of the modeling process in order to build the simulation model. 


\section{Acknowledgements}

This work was supported by Higher Education in Poland, statutory activities DS3600/WIPiE/2018, Faculty of Production and Power Engineering, University of Agriculture in Krakow.

\section{References}

[1] Francik S., Pedryc N., Knapczyk A. etc. Bibliometric Analysis of Multiple Critteria Decision Making in Agriculture. Technical Sciences, vol. 20, no. 1, 2017, pp. 17-30.

[2] Lukic D., Milosevic M., Antic A. etc. Multi-criteria selection of manufacturing processes in the conceptual process planning. Advances in Production Engineering \& Management, vol. 12, no. 2, 2017, pp. 151-162.

[3] Simeunovic N., Kamenko I., Bugarski V. etc. Improving workforce scheduling using artificial neural networks model. Advances in Production Engineering \& Management, vol. 12, no. 4, 2017, pp. 337-352.

[4] Zhou F.L., Wang X., He Y.D. etc. Production lot-sizing decision making considering bottleneck drift in multi - stage manufacturing system. Advances in Production Engineering \& Management, vol. 12 , no. 3, 2017, pp. 213-220.

[5] Bako B., Božek P. Trends in simulation and planning of manufacturing companies. Procedia Engineering, vol. 149, June 2016, pp. 571-575.

[6] Halická M., Trnovská M. The Russell measure model: Computational aspects, duality, and profit efficiency. European Journal of Operational Research, vol. 268, 2018, pp. 386-397.

[7] Jia Y., Tian H., Chen C. etc. Predicting the availability of production lines by combining simulation and surrogate model. Advances in Production Engineering And Management, vol. 12, no. 3, 2017, pp. 285-295.

[8] Kikolski M. Study of Production Scenarios with the Use of Simulation Models. Procedia Engineering, vol. 182, 2017, pp. 321-328.

[9] Philippot S. Simulation models of short-rotation forestry production and coppice biology. Biomass and Bioenergy, vol. 11, no. 2-3, 1996, pp. 85-93.

[10] Merot A., Bergez J.E., Capillon A. etc. Analysing farming practices to develop a numerical, operational model of farmers' decision-making processes: An irrigated hay cropping system in France. Agricultural Systems, vol. 98, no. 2, 2008, pp. 108-118.

[11]Zhang Y, Munir M.T., Udugama I. etc. Modelling of a milk powder falling film evaporator for predicting process trends and comparison of energy consumption. Journal of Food Engineering, vol. 225, 2018, pp. 26-33.

[12] Sørensen C.G., Nielsen V. Operational analyses and model comparison of machinery systems for reduced tillage. Biosystems Engineering, vol. 92, no. 2, 2005, pp. 143-155.

[13] Pabis S., Jaros M., Wieremiejczyk W. Doskonalenie procesu zbioru i transportu ziarna zbóż metodą symulacji komputerowej. Część I: Modelowanie systemów agrotechnicznych. (Improving the process of harvesting and transporting cereal grains by computer simulation. Part I: Modeling of agrotechnic). Roczniki Nauk Rolniczych, vol. 75-NaN-2, 1981. (In Polish).

[14] Bal R., Bieranowski J., Piechocki J. Model systemu wytwarzania i wykorzystania odnawialnych nośników energetycznych pochodzenia rolniczego. Cz. I. Model relacyjny systemu wytwarzania i wykorzystania odnawialnych nośników energii (Model of a system generating and utilizing renewable energetic). Inżynieria Rolnicza, vol. 14, 2005, pp. 7-14. (In Polish).

[15] Bieranowski J. Model systemu utrzymania wybranych maszyn przemysłu rolno-spożywczego (Model of a maintenance system for selected machin ery in the food processing industry). Inżynieria Rolnicza, vol. 43, no. 1, 2003. (In Polish).

[16] Bieranowski J., Nalepa K. Model relacyjny zintegrowanego systemu energetycznego w wiejskim budynku mieszkalnym (Relational model of integrated energy system designed for rural habitable building). Inżynieria Rolnicza, vol. 61, no. 1, 2005, pp. 23-31. (In Polish)

[17]Mueller W., Boniecki P., Weres J. etc. Modelowanie danych w procesie odwzorowywania informatycznego systemów empirycznych stanowiących przedmiot inżynierii rolniczej (Data modeling in a process of mapping empirical systems of agricultural engineering onto information systems). Inżynieria Rolnicza, vol. 94, no. 6, 2007, pp. 175-182. (In Polish). 
[18] Ślipek Z., Francik S., Łapczyńska-Kordon B. Modelowanie złożonego systemu produkcji - model relacyjny gospodarstwa sadowniczego (The modelling of complex production system - relation model of fruit farm). Inżynieria Rolnicza, vol. 115, no. 6, 2009, pp. 277-284. (In Polish).

[19] Jaros M., Pabis S. Inżynieria systemów (System engineering). Warszawa: Wydawnictwo SGGW, 2007. (In Polish).

[20] Baldo T.A., Morabito R., Santos M.O. etc. Alternative Mathematical Models and Solution Approaches for Lot-Sizing and Scheduling Problems in the Brewery Industry: Analyzing Two Different Situations. Mathematical Problems in Engineering, vol. 2017, 2017, pp. 1-18.

[21] Ferreira D., Morabito R., Rangel S. Relax and fix heuristics to solve one-stage one-machine lotscheduling models for small-scale soft drink plants. Computers and Operations Research, vol. 37 , no. 4, 2010, pp. 684-691.

[22] Wang Y.-C. Kinematical Modeling for Main Machines and Integrating into Beverage Packaging Production Line. In: Advanced Design and Manufacture to Gain a Competitive Edge. Yan X.T., Jiang C., Eynard B., Eds. London: Springer, 2008, pp. 510-635.

[23] Struss P., Ertl B. Post-mortem diagnosis of bottling plants based on recorded data. IFAC Proceedings Volumes (IFAC-PapersOnline), no. 233, 2009, pp. 1330-1335.

[24] Voigt T., Flad S., Struss P. Model-based fault localization in bottling plants. Advanced Engineering Informatics, vol. 29, no. 1, 2015, pp. 101-114.

[25] Muster-Slawitsch B., Hubmann M., Murkovic M. etc. Process modelling and technology evaluation in brewing. Chemical Engineering and Processing: Process Intensification, vol. 84, 2014, pp. 98-108. 